\title{
PENGARUH PENGGUNAAN PANDUAN TANGGAP BENCANA TERHADAP STRATEGI KOPING KELUARGA DALAM MENGHADAPI KERENTANAN BENCANA TSUNAMI DI DESA GUNTURHARJO KABUPATEN WONOGIRI
}

\author{
Suyanto, Hartono \\ Poltekkes Kemenkes Surakarta Jurusan Keperawatan
}

\begin{abstract}
Background: Tsunamis are one of the most frequent disasters in Indonesia and are very risky along the southern coast of the island of Java, including the area of Wonogiri Regency which has a southern coastline. The tsunami resulted in losses not only of loss of property and lives but also of the psychosocial impact of mental health disorders. Therefore tsunami disaster preparedness is carried out not only on physical aspects but also psychosocial aspects such as disaster response by improving family coping strategies. Methods: This study wanted to see the effect of using disaster response guidebooks on family coping strategies to deal with tsunamis. The population of this study were people living in the coastal area of Nampu, Guntur Harjo sub district, Parang Gupito, Wonogiri Regency, Central Java, with a sample of 240 households. The study design used one group pre-post test with a quasi-experimental approach where the research data collected was analyzed using Chi Square test. Result: The results showed that $p$ Value $=0,000<0,005$ so it can be concluded that there are differences in family coping strategies between before and after using the tsunami disaster response guidelines. Conclusion: It is recommended to continue preparedness efforts and disaster response efforts using existing guidelines and conduct research on areas that have different characteristics.
\end{abstract}

Keywords: Guidebook, Tsunami, Koping Family

\section{PENDAHULUAN}

Indonesia merupakan bagian dari deret gunung berapi sepanjang AsiaPasifik yang sering di sebut sebagai Ring of Fire. Hal tersebut terjadi karena diwilayah ini banyak terdapat patahan aktif dan sering terjadi gempa bumi, seperti yang terjadi di wilayah bagian barat bukit barisan, pesisir pantai selatan Jawa, dan pesisir pantai utara Papua. pesisir timur Sumatera, pesisir Utara Jawa, dan pesisir selatan Papua.

Kondisi tersebut membuat negara Indonesia sering mengalami bencana. Menurut data yang dihimpun dalam Data Informasi Bencana Indonesi (DIBI), telah terjadi lebih dari 1.800 kejadian bencana pada periode tahun 2005 hingga 2015. Berbagai bentuk bencana yang terjadi antara lain bencana geologi seperti gempa bumi, tsunami, letusan gunungapi, dan tanah longsor. Kecenderungan jumlah kejadian bencana relatif terus meningkat yang banyak menimbulkan dampak yang cukup besar baik dari sisi korban dan kerugian ekonomi (Badan Nasional Penanggulangan Bencana, 2018).

Tsunami merupakan salah satu ancaman bencana untuk banyak wilayah pesisir di Indonesia. Bencana ini umumnya dipicu oleh terjadinya 
gempabumi di laut yang menyebabkan pergeseran secara vertikal didasar laut.

Catatan kejadian tsunami tahun 1907 yang terjadi di sekitar Pulau Simeulue, Provinsi Aceh. Kemudian bencana tsunami tanggal 26 Desember 2004 yang meluluhlantakkan kawasan pesisir Samudera Hindia juga sudah menjadi catatan sejarah bencana yang sangat kelam di Indonesia.

Untuk itu pemeritah Indonesia dalam merespon dan menanggapi bencana yang sering terjadi mengeluarkan Peraturan Pemerintah No. 21 tahun 2008 tentang Penyelenggaraan Penanggulangan Bencana. Pada bagian 2 tentang situasi tidak terjadi bencana, pasal 5 diatur tentang penyelenggaraan penanggulanagan bencana dalam situasi tak tejadi bencana antara lain pengurangan resiko bencana seperti mengurangi faktor kerentanan (BNPB, 2008). Peraturan Pemerintah No 21 tahun 2008 tersebut merupakan merupakan penjabaran untuk melaksanakan Undang Undang No. 24 tahun 2007 tentang penanggulangan Bencana.

Walaupun sudah memiliki pengalaman karena sering terjadi bencana di Indonesia, tetapi ketika terjadi bencana dimana sumber bencana relatif dekat sehingga hanya memiliki waktu yang singkat untuk melakukan upaya antisipasi atau evakuasi, maka akan terjadi kepanikan yang luar biasa. Dengan demikian pemerintah yang bertanggungjawab mengatur dan memberikan bantuan dan pertolonganpun tidak langsung bisa menjalankan fungsinya dengan baik karena sebagian aparat menjadi korban dan sebagian yang lain menyelamatkan diri dan keluargannya

Di provinsi jawa Tengah terdapat empat kabupaten yang memiliki potensi terjadi tsunami diantaranya yaitu : kabupaten Cilacap, Kabupaten Purwrejo, Kabupaten Kebumen dan Kabupaten Wonogiri (BPBD Jateng, 2017).

Dikabupaten Wonogiri ada lima bencana yang sering terjadi yaitu kekeringan yang kerap terjadi di 8 kecamatan, tanah longsor di 118 desa, puting beliung di 109 desa, banjir di 52 desa, gempa bumi di 82 desa serta potensi tsunami di satu kecamatan yakni kecamatan Paranggupito (Setyono \& Hidayati, 2015). Untuk itu butuh kesiapsiagaan dan ketrampilan yang mumpuni yang wajib di miliki oleh keluarga.

Pemerintah Kabupaten Wonogiri telah melakukan simulasi-simulasi yang bersifat gladi di lapangan belum menyentuh persiapan-persiapan bagi individu di kel uarga. Sehingga simulasi ini dipandang belum cukup sebagai cara untuk mengurangi korban bencana ini, tetapi dibutuhkan pengetahuan yang cukup untuk unit terkecil di masyarakat yaitu keluarga.

Belum adanya rencana keluarga menghadapi bencana, dapat dilihat dari kurang tanggapnya manajemen bencana di tingkat pemerintah lokal dan nasional. Untuk mengantisipasi bencana, masing-masing anggota keluarga perlu menyusun suatu perencanaan untuk menghadapinya. Karena hal ini akan membantu keluarga untuk lebih tenang menghadapi bencana.

Keluarga yang tinggal di pesisir pantai Paranggupito belum semuanya mengikuti pelatihan simulasi bencana dan mendengar apa yang harus dilakukan pada saat bencana. Keluarga hanya berpatokan pada perubahan alam dan atau cuaca dari arah laut. Mereka karena dekat dari pantai, seandainya terlihat air laut 
tidak surut, keluarga memilih untuk tidak meninggalkan rumah. Mereka tidak ada sama sekali melakukan antisipasi ataupun persiapan-persiapan untuk menghadapi kondisi-kondisi kritis yang kemungkinan bisa terjadi.

\section{METODE PENELITIAN}

Tujuan penelitian ini adalah untuk mengetahui pengaruh panduan tanggap bencana terhadap strategi koping keluarga dalam menghadapi kerentanan bencana tsunami di desa Gunturharjo kabupaten Wonogiri. Hasil penelitian ini menjadi masukan bagi pemerintah dalam hal manajemen bencana. Metode yang digunakan adalah quasi eksperimental pre test - post test yang dilakukan dilakukan di desa Gunturharjo, Kecamatan Paranggupito, Kabupaten Wonogiri pada tahun 2018. Populasi penelitian ini adalah Kepala keluarga sebanyak 542 KK. Pengambilan sampel menggunakan tabel Krecjie diperoleh jumlah sebesar $226 \mathrm{KK}$ dibulatkan menjadi $240 \mathrm{KK}$.

Pengumpulan data menggunakan kuesioner dan buku saku yang dikembangan dari buku Pedoman Menghadapi Bencana Gempa dan Tsunami (UNESCO, 2007). Adapun langkah pengumpulan data dilakukan melalui tahap pertama menentukan kepala keluarga dan membagikan kuesioner pre test untuk di jawab.

Selanjutnya Kepala Keluarga sebagai responden dikumpulkan dan diberikan penjelasan serta bagikan buku saku Panduan Tanggap Bencana Tsunami.

Responden diberikan kesempatan selama satu sampai dua minggu untuk mempelajari dan memahami isi buku pedoman tersebut. Terakhir dibagikan kuesioner post test untuk di jawab. Data dianalisa dengan menggunakan uji chisquare

\section{HASIL PENELITIAN}

Tabel 1. Karakteristik Responden

Berdasarkan Usia dan tingkat pendidikan

\begin{tabular}{|c|c|c|c|c|c|c|c|c|}
\hline \multirow{3}{*}{$\begin{array}{l}\text { Usia } \\
\text { Tingkat } \\
\text { Pendidikan }\end{array}$} & \multirow[b]{3}{*}{$\mathrm{f}$} & \multirow[t]{2}{*}{$<45$} & \multicolumn{2}{|c|}{$45-$} & \multirow{2}{*}{\multicolumn{2}{|c|}{$>65$}} & \multirow{2}{*}{$\begin{array}{l}\text { Tot } \\
\text { al }\end{array}$} & \multirow[b]{3}{*}{$\%$} \\
\hline & & & 65 & & & & & \\
\hline & & $\%$ & $\mathrm{f}$ & $\%$ & $f$ & $\%$ & $\mathbf{f}$ & \\
\hline Tidak & 0 & 0 & 30 & 1 & 3 & 1 & 60 & 25 \\
\hline Sekolah & & & & 4 & 0 & 3 & & \\
\hline SD & $\begin{array}{r}11 \\
5\end{array}$ & 48 & 40 & $\begin{array}{l}1 \\
5\end{array}$ & 0 & 0 & 155 & 65 \\
\hline SMP/SMA & 20 & 8 & 5 & 2 & 0 & 0 & 25 & 10 \\
\hline PT & 0 & 0 & 0 & 0 & 0 & 0 & 0 & 0 \\
\hline Total & $\begin{array}{r}13 \\
5\end{array}$ & 56 & 75 & $\begin{array}{l}3 \\
1\end{array}$ & $\begin{array}{l}3 \\
0\end{array}$ & $\begin{array}{l}1 \\
3\end{array}$ & 240 & 100 \\
\hline
\end{tabular}

Berdasarkan tabel 1 terlihat bahwa sebagian besar (48 \%) usia responden antara $<45$ tahun dengan tingkat pendidikan Sekolah Dasar. Sedangkan yang berpendidikan tinggi tidak ada dan responden yang tidak sekolah dijumpai sebanyak 60 orang $(25 \%)$.

Tabel 2. Karakteristik Responden berdasarkan Pekerjaan dan Jarak Rumah ke Pantai

$\begin{array}{lcccc} & <0,5 \mathrm{~km} & 0,5-1 & >1 \mathrm{~km} & \text { Total } \\ \text { Jarak } & & \mathrm{km} & & \mathrm{f}\end{array}$

\section{Pekerjaan}

\begin{tabular}{lrrrrrrrr} 
& $\mathrm{f}$ & \multicolumn{1}{c}{$\%$} & $\mathrm{f}$ & \multicolumn{1}{c}{$\%$} & $\mathrm{f}$ & \multicolumn{1}{c}{$\%$} & \multicolumn{2}{c}{$\%$} \\
\hline PNS & - & 0 & 0 & 0 & 0 & 0 & 0 & 0 \\
TNI/Polri & 0 & 0 & 0 & 0 & 0 & 0 & 0 & 0 \\
Swasta & 35 & 14 & 25 & 10 & 2 & 10, & 85 & 35,5 \\
Tani/Nelay & 35 &, 5 & 90 &, 5 & 5 & 5 & 90 & 64,5 \\
an/Buruh & & 14 & & 37 & 3 & 12, & & \\
& &, 5 & &, 5 & 0 & 5 & & \\
Total & 70 & 29 & 11 & 48 & 5 & 23 & 240 & 100 \\
& & & 5 & & 5 & & & \\
\hline
\end{tabular}

Berdasarkan tabel 2 terlihat bahwa pekerjaan responden sebagai nelayan/ petani/ buruh dan swasta adalah pekerjaan terbanyak dan tidak ada responden yang bekerja sebagai PNS, TNI/Polri. 
Sedangkan jarak tempat tinggal ke pantai terbanyak berjarak $0,5-1 \mathrm{~km}$ sebanyak $48 \%$.

Tabel. 3 Tingkat Pengetahuan Responden sebelum menggunakan Panduan tanggap bencana Tsunami

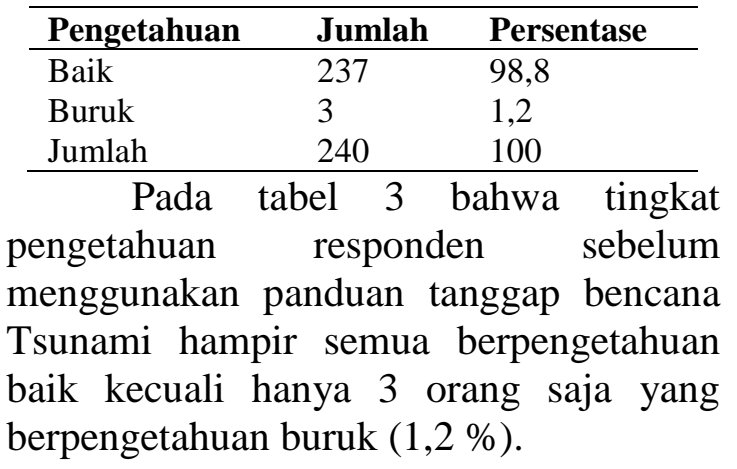

Tabel 4. Tingkat Pengetahuan Responden sesudah menggunakan Panduan tanggap bencana Tsunami

\begin{tabular}{|c|c|c|}
\hline Koping Keluarga & f & $\%$ \\
\hline Efektif & 123 & 51 \\
\hline Tidak efektif & 117 & 49 \\
\hline Jumlah & 240 & 100 \\
\hline
\end{tabular}

Berdasarkan tabel 4 terlihat

bahwa tingkat pengetahuan responden sesudah menggunakan panduan tanggap bencana Tsunami dari 240 orang responden tinggal 1 orang responden yang memiliki pengetahuan buruk.

Tabel 5. Pengetahuan responden sebelum dan sesudah menggunakan Panduan tanggap bencana Tsunami

\begin{tabular}{|c|c|c|c|c|c|c|c|}
\hline \multirow{3}{*}{$\begin{array}{l}\text { Pengetahuan } \\
\text { Sebelum } \\
\text { menggunakan }\end{array}$} & \multicolumn{4}{|c|}{$\begin{array}{c}\text { Sesudah } \\
\text { menggunakan }\end{array}$} & \multirow{2}{*}{\multicolumn{2}{|c|}{ Total }} & \multirow[t]{3}{*}{ p. value } \\
\hline & & aik & & cuk & & & \\
\hline & $\mathrm{N}$ & $\%$ & $\mathrm{n}$ & $\%$ & $\mathrm{n}$ & $\%$ & \\
\hline Baik & $\begin{array}{l}23 \\
7\end{array}$ & 99 & 1 & 0,5 & $\begin{array}{l}33 \\
8\end{array}$ & 99,5 & 0,989 \\
\hline Buruk & 2 & 0,5 & 0 & 0 & 2 & 0,5 & \\
\hline Jumlah & $\begin{array}{l}23 \\
9\end{array}$ & 99,5 & 1 & 0,5 & $\begin{array}{l}24 \\
0\end{array}$ & 100 & \\
\hline
\end{tabular}

Berdasarkan tabel 5 terlihat bahwa pengetahuan respondeni sebelum dan sesudah menggunakan panduan tanggap bencana tsunami memiliki nilai $\mathrm{p}$ value $0,989>0,05$. Dengan demikian berarti tidak memiliki perbedaan antara sebelum dan sesudah menggunakan panduan tanggap bencana Tsunami.

Tabel 6. Koping Keluarga Sebelum menggunakan panduan tanggap bencana tsunami

$$
\text { Pengetahuan Jumlah Persentase }
$$

\begin{tabular}{lrr}
\hline Baik & 239 & 99,5 \\
Buruk & 1 & 0,5 \\
Jumlah & 240 & 100 \\
\hline
\end{tabular}

Berdasarkan tabel 6 terlihat bahwa koping responden sebelum menggunakan panduan tanggap bencana tsunami $51 \%$ efektif dan $49 \%$ tidak efektif.

Tabel 7. Koping Keluarga Sesudah menggunakan panduan tanggap bencana tsunami

\begin{tabular}{lrr}
\hline $\begin{array}{c}\text { Koping } \\
\text { Keluarga }\end{array}$ & f & \% \\
\hline Efektif & 210 & 87,5 \\
Tidak & 30 & 12,5 \\
efektif & & \\
Jumlah & 240 & 100 \\
\hline
\end{tabular}

Selanjutnya berdasarkan tabel 7 terlihat bahwa koping responden sesudah menggunakan panduan tanggap bencana tsunami berubah menjadi 210 responden $(87,5 \%)$ efektif dan sisanya 30 responden $(12,5 \%)$ tidak efektif 
Tabel 8. Koping keluarga sebelum dan sesudah menggunakan panduan tanggap bencana tsunami.

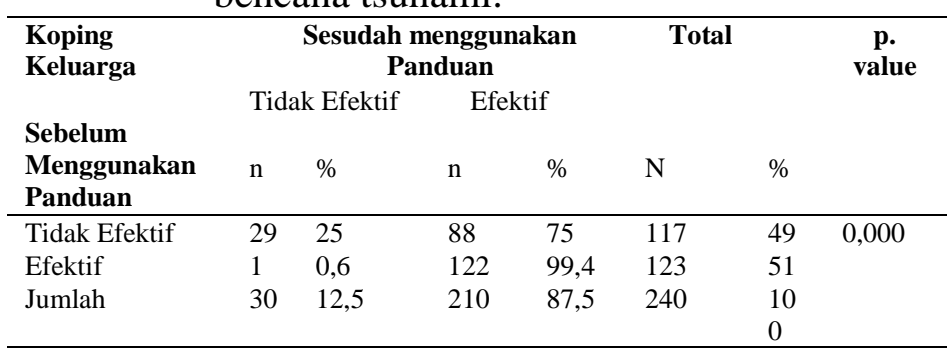

Berdasarkan tabel 8 terlihat bahwa koping responden sebelum dan sesudah menggunakan panduan tanggap bencana tsunami memiliki nilai $\mathrm{p}$ value $0,000<$ 0,05 . Dengan demikian berarti terdapat perbedaan antara sebelum dan sesudah menggunakan panduan tanggap bencana tsunami.

Tabel 9. Hasil Observasi Kelengkapan Tas Punggung Keluarga tanggap Bencana

\begin{tabular}{lcc}
\hline Hasil Observasi & F & \% \\
\hline Lengkap & 97 & 41 \\
Tidak lengkap & 143 & 59 \\
Jumlah & 240 & 100 \\
\hline
\end{tabular}

Tabel 9 memperlihatkan bahwa tas punggung keluarga tanggap bencana sebagai besar (59\%) pelengakapanya tidak lengkap.

\section{PEMBAHASAN}

Bencana diartikan sebagai peristiwa atau serangkaian peristiwa yang mengancam dan mengganggu kehidupan dan penghidupan masyarakat yang disebabkan baik oleh faktor alam dan/atau faktor non alam maupun faktor manusia sehingga mengakibatkan timbulnya korban jiwa manusia, kerusakan lingkungan, kerugian harta benda, dan dampak psikologis.

Demikian halnya dengan bencana akibat tsunami yang dapat menimbulkan kerugian jiwa dan harta benda.
Guna mengurangi kerugian yang diakibatkan oleh bencana seperti tsunami maka peningkatan tingkat kapasitas masyarakat dalam menghadapi bencana tsunami merupakan elemen penting guna mengetahui tingkat kesiapsiagaan masyarakat dalam menghadapi bencana tsunami yang dapat terjadi di masa mendatang sehingga dampaknya dapat diminimalkan. Peningkatan kapasistas tersebut antara lain dengan cara membuat strategi koping keluarga yang efektif dalam menghadapi bencana tsunami.

Berikut ini akan disajikan pembahasan hasil penelitian yang telah dilakukan

\section{PEMBAHASAN}

Berdasarkan hasil pengumpulan data menggunakan kuesioner yang dilakukan sebelum dan sesudah menggunakan panduan tanggap bencana tsunami dan dilanjutkan dengan menganalisanya diperoleh hasil bahwa tingkat pengetahuan responden adalah baik. Hal tersebut dapat dilihat baik sebelum menggunakan panduan tanggap bencana tsunami hampir semua responden sebanyak $337 \quad(98,8 \%)$ berpengetahuan baik dan hanya 3 orang $(1,2 \%)$ yang berpengetahuan buruk. Sedangkan sesudah menggunakan panduan tanggap bencana tsunami terjadi peningkatan dimana hanya terdapat 1 (satu) responden yang berpengetahuan buruk.

Kabupaten Wonogiri merupakan wilayah yang memiliki karakteristik kondisi fisik alamiah yang unik dan rawan terhadap terjadinya bencana alam. Kondisi fisik alamiah termasuk didalamnya aspek topografi, klimatologi dan litologi merupakan determinan penting untuk mengevaluasi tingkat kerentanan 
lingkungan (Setyono \& Hidayati, 2015). Isu-isu lingkungan seperti bencana alam juga merupakan faktor yang berpengaruh terhadap kerentanan lingkungan.

Jika dilihat dari sensitivitasnya, wilayah di Kabupaten Wonogiri cenderung masuk dalam kategori sensitivitas rendah. Pada tingkat kapasitas adaptif, wilayah Kabupaten Wonogiri sebagian besar masuk dalam kategori kapasitas adaptif rendah. Melihat kondisi tersebut diperlukan peningkatan kapasistas bagi masyarakat khususnya keluarga dalam menghadapi bencana tsunami

$\begin{array}{cccr}\text { Hal } & \text { tersebut } & \text { sejalan } & \text { dengan } \\ \text { pendapat } & \text { (Hidayati, } & 2012) & \text { yang }\end{array}$ menyatakan bahwa paradigma pengurangan risiko bencana merubah pola pikir yang responsif menjadi preventif. Apabila suatu wilayah mempunyai risiko tinggi maka upaya pengurangan risiko dilakukan dengan melakukan tindakan-tindakan. Pertamatama dilakukan tindakan untuk memisahkan potensi bencana yang mengancam dengan elemen berisiko (element at risk). Tindakan ini dikenal dengan pencegahan (risk avoidance).

Apabila antara potensi bencana dengan elemen berisiko tersebut tidak dapat dipisahkan (harus bertemu) maka upaya yang dilakukan adalah pengurangan risiko (risk reduction), atau dikenal dengan mitigasi dilanjutkan dengan upaya-upaya kesiapsiagaan yang dapat dalam bentuk upaya peningkatan kapasitas masyakat khususnya keluarga dalam menghadapi tsunami.

Bentuk operasional peningkatan kapasitas keluarga dalam menghadapi bencana tsunami dapat dilakukan oleh perawat sebagai profesi yang ikut bertanggung jawab pada masyarakat dalam berbagai bentuk seperti memberikan pendidikan, pelatihan dan memberikan buku panduan. (Putra, 2017) menyatakan bahwa selama paruh terakhir abad ke-20, fokus keperawatan berubah dari rumah dan lapangan ke klinik atau rumah sakit berteknologi tinggi. Sedangkan perawatan tanpa teknologi atau bencana alam hampir menghilang dari kurikulum banyak pendidikan perawat.

Banyak peristiwa dan ancaman bencana di awal abad 21 menyebabkan pendidik dan praktisi untuk meningkatkan penekanan pada keperawatan bencana dan prinsip-prinsip yang memandu praktik perawat dalam menanggapi bencana.

Berbagai penelitian dan upaya untuk mengetahui dan meningkatkan kapasitas masyarakat dalam menghadapi bencana tsunami pernah dilakukan. Seperti (Muttarak \& Pothisiri, 2013) yang telah melakukan penelitian tentang seberapa baik penduduk pantai Andaman di provinsi Phang Nga, Thailand, siap menghadapi gempa bumi dan tsunami. Diperoleh hasil bahwa pendidikan formal dapat meningkatkan kesiapsiagaan bencana karena pendidikan meningkatkan keterampilan kognitif.

Sedangkan penelitian

Kesiapsiagaan Masyarakat Kawasan Teluk Pelabuhan Ratu Terhadap Bencana Gempa Bumi dan Tsunami oleh (Paramesti, 2013) diketahui bahwa kesiapsiagaan masyarakat di Kawasan Teluk Pelabuhan Ratu terhadap bencana gempa bumi dan tsunami berada dalam kondisi tidak siap jika dilihat dari parameter pengetahuan dan sikap. Tidak siapnya masyarakat dalam menghadapi ancaman bencana ini antara lain disebabkan banyak masyarakat yang tidak 
mengetahui kerentanan wilayahnya terhadap bencana.

Sementara itu belum banyak upaya peningkatan kesiapsiagaan bencana yang dilakukan oleh pemerintah karena terbatasnya sumber daya. Namun demikian, kondisi kesiapsiagaan masyarakat di Kawasan Teluk Pelabuhan Ratu ini masih dapat ditingkatkan sehingga resiko yang terjadi dapat ditekan.

Dengan demikian pengetahuan yang baik tentang tsunami sangat diperlukan agar masyarakat atau keluarga tanggap terhadap bahaya bencana tsunami yang sewaktu waktu dapat terjadi

Hasil pengumpulan data koping keluarga terhadap bencana tsunami menggunakan kuesioner yang dilakukan sebelum dan sesudah menggunakan panduan tanggap bencana tsunami dan dilanjutkan dengan menganalisanya diperoleh hasil bahwa koping responden sebelum menggunakan panduan tanggap bencana hampir sama antara yang efektif dan tidak efektif yaitu $51 \%$ ( 123 responden) efektif dan 49\% (117 responden) tidak efektif. Sedangkan sesudah menggunakan panduan tanggap bencana terjadi peningkatan koping yang efektif yaitu sebanyak $87,5 \% \quad(210$ reponden) kopingnya efektif dan koping responden yang tidak efektif sebanyak $12,5 \%$ (30 responden).

Selanjutnya berdasarkan hasil analisa perbedaan strategi koping keluarga antara sebelum dan sudah menggunakan panduan tanggap bencana tsunami diperoleh hasil $p$ value $0,00<0,05$. Dengan demikian hipotesa terdapat perbedaan strategi koping keluarga sebelum dan sesudah menggunakan panduan tanggap bencana menghadapai kerentanan bencana Tsunami di desa
Gunturharjo, Kecamatan Paranggupito, kabupaten Wonogiri diterima.

Hasil penelitian yang demikian dapat dijelaskan sebagai berikut: Sebuah penelitian yang dilakukan di sepanjang pantai tenggara India dan mengakibatkan kerugian yang sangat besar dan terganggunya kesehatan mental jangka panjang. Diperoleh hasil tentang mekanisme koping etno-kultural masyarakat yang terkena dampak tsunami. (Rajkumar, Premkumar, \& Tharyan, 2008).

Hasil peneitian ini menunjukkan bahwa strategi koping diperlukan agar pada saat tejadi bencana maka dampaknya dapat diminimalisir buka hanya dampak kerugian kehilangan harta benda tetapi juga dampak psikologis yang dapt mengganggu kesehatn mental.

Penelitian lain yang dilakukan oleh (Restiadi, 2013) tentang science, environment, technology, society (SETS) dalam menumbuhkan sikap tanggap bencana tsunami bertujuan mengembangkan perangkat pembelajaran bervisi SETS IPA yang valid, efektif, dan praktis. Hasil penelitian menyatakan bahwa pembelajaran tuntas dapat diperoleh dengan hasil baik dimana lebih dari $75 \%$ siswa tumbuh sikap tanggapnya

\section{KESIMPULAN DAN SARAN}

Kesimpulan hasil penelitian ini adalah: Tidak terdapat perbedaan pengetahuan tentang tanggap bencana tsunami antara sebelum dan sesudah menggunakan panduan tanggap bencana tsunami. Tetapi terdapat perbedaan koping keluarga antara sebelum dan sesudah menggunakan panduan tanggap bencana

Saran berdasarkan hasil penelitian dan pembahsannya yaitu: Pengetahuan tentang tanggap bencana tsunami yang 
telah baik dapat menjadi pendorong untuk meningkatkan sikap terhadap tsunami seperti melengkapi tas punggung tanggap bencana. Bagi peneliti lain disarankan untuk melajutkan penelitian ini di wilayah pantai yang memiliki resiko tsunami dengan topografi datar.

\section{DAFTAR RUJUKAN}

Badan Nasional Penanggulangan Bencana. (2018). Data Informasi Bencana Indonesia (DIBI). Nopember 2018. https://doi.org/10.1086/305782

BNPB. Peraturan Pemerintah No. 21 tahun 2008 (2008). Retrieved from https://www.bnpb.go.id/ppid/file/P P_No._21_Th_2008.pdf

BPBD Jateng. (2017). Laporan Tahunan Pelaksanaan Program Kerja Ta 2017. Retrieved from http://bpbd.jatengprov.go.id/PPID/ wp-content/uploads/2018/06/SKKalakhar-BPBD-ttg-KlasifikasiInformasi-Publik-2017.pdf

Hidayati, D. (2012). Striving to reduce disaster risk: Vulnerable communities with low levels of preparedness in Indonesia. Journal of Disaster Research. Retrieved from

https://www.fujipress.jp/jdr/dr/dsst r000700010075/

Muttarak, R., \& Pothisiri, W. (2013). The role of education on disaster preparedness: Case study of 2012 Indian Ocean earthquakes on Thailand's Andaman coast. Ecology and Society. https://doi.org/10.5751/ES-06101180451

Paramesti, C. A. (2013). Kesiapsiagaan Masyarakat Kawasan Teluk
Pelabuhan Ratu Terhadap Bencana Gempa Bumi dan Tsunami. Journal of Regional and City Planning. https://doi.org/10.1007/s12525009-0012-4

Putra, A. (2017). Nurses Role and Leadership in disaster management at the emergency response. Idea Nursing Journal. Retrieved from http://www.jurnal.unsyiah.ac.id/IN J/issue/view/701

Rajkumar, A. P., Premkumar, T. S., \& Tharyan, P. (2008). Coping with the Asian tsunami: Perspectives from Tamil Nadu, India on the determinants of resilience in the face of adversity. Social Science and Medicine. https://doi.org/10.1016/j.socscimed .2008 .05 .014

Restiadi, T. P. (2013). Upaya penumbuhan sikap tanggap bencana tsunami melalui pembelajaran bervisi SETS IPA kelas V sekolah dasar. Journal of Primary Educational. Retrieved from

https://journal.unnes.ac.id/sju/inde x.php/jpe/article/view/3071

Setyono, J. S., \& Hidayati, I. Y. (2015). Tingkat Kerentanan Lingkungan Kabupaten Wonogiri. Jurnal Teknik PWK. Retrieved from https://ejournal3.undip.ac.id/index. php/pwk/article/view/9827

UNESCO. (2007). Pedoman menghadapi bencana gempa dan tsunami. Retrieved from https://unesdoc.unesco.org/ark:/48 223/pf0000154757 